\title{
Pengaruh Viral Marketing Video Promosi Instagram terhadap Keputusan Pembelian Konsumen Bakso Goreng iONG
}

\author{
Velia, Diah Ayu Candraningrum \\ velia.915160125@stu.untar.ac.id,diahc@fikom.untar.ac.id \\ Fakultas Ilmu Komunikasi Universitas Tarumanagara
}

\begin{abstract}
Current development is driving a growth for technology and media in marketing strategy. One of the marketing strategy is viral marketing. Viral marketing could be a strategy to do a promotion for delivering information from sales to consumer by social media. This research conducts to find out about whether there is any effect of viral marketing Instagram promotion video on consumer purchase decision Bakso Goreng iONG. This study uses a descriptive approach in descriptive method, with the amount of 114 respondents who were the viewers from Instagram promotion video and have purchased Bakso Goreng iONG product. The result of this research mentioned, by significance test partial effect, shows that viral marketing individually has an effect on purchasing decisions. One of the supporting component to running viral marketing is buzz, which is the content, ideas and topics from the promotional video submitted. With an interesting and clear topic about information from Bakso Goreng iONG, made the consumer has an interest to buy Bakso Goreng iONG product.
\end{abstract}

Keywords: bakso goreng iong, purchase decision, viral marketing.

\begin{abstract}
Abstrak
Perubahan zaman mendorong adanya perkembangan teknologi dan media dalam melakukan strategi pemasaran. Salah satunya adalah viral marketing, yang dapat dilakukan sebagai strategi untuk menerapkan promosi guna menyampaikan informasi dari pemasar pada konsumen lewat media sosial. Penelitian ini berfungsi untuk mengetahui adakah pengaruh viral marketing video promosi Instagram, terhadap keputusan pembelian konsumen pada produk Bakso Goreng iONG. Metode deskriptif merupakan pendekatan yang digunakan dalam penelitian ini, dengan total jumlah 114 responden yang merupakan penonton dari video promosi Instagram, dan telah membeli produk Bakso Goreng iONG. Hasil penelitian menyebutkan, lewat uji signifikasi pengaruh parsial, menunjukkan hasil bahwa viral marketing secara individual memiliki pengaruh terhadap keputusan pembelian. Salah satu komponen dalam mendukung berjalannya viral marketing adalah buzz/content, yang merupakan isi, ide dan topik dari video promosi yang disampaikan. Dengan topik yang menarik dan jelas mengenai informasi dari produk yang dipasarkan oleh Bakso Goreng iONG, membuat konsumen tertarik untuk membeli produk Bakso Goreng iONG.
\end{abstract}

Kata Kunci: bakso goreng iong, keputusan pembelian, viral marketing.

\section{Pendahuluan}

Perubahan zaman mendorong terjadinya perkembangan teknologi dalam kehidupan masyarakat. Masyarakat memiliki kehidupan yang lebih cepat, efektif, dan efisien dengan adanya perkembangan teknologi. Terutama dalam aktivitas komunikasi yang bertujuan untuk menyampaikan pesan dari pengirim kepada penerima. Miller (1976) dalam Mulyana (2013) menyampaikan bahwa untuk mempengaruhi perilaku penerima, komunikasi terjadi ketika suatu sumber menyampaikan suatu pesan kepada 
penerima. Perkembangan teknologi membawa perubahan aktivitas komunikasi masyarakat, hal ini membuat masyarakat mengikuti perkembangan tersebut dan terus menggunakan teknologi untuk berkomunikasi.

Salah satu kemajuan teknologi yang digunakan oleh masyarakat untuk berkomunikasi pada zaman ini adalah new media. Martin dan Creeber (2009) mendefinisikan new media atau media baru merupakan mediasi teknologi yang terdapat bersama dengan komputer digital, sebagai bentuk produk dari komunikasi. Program yang dapat diimplementasikan dalam komunikasi pemasaran melalui media baru adalah strategi pemasaran viral (viral marketing). Swanepoel (2009) dalam Kaloka (2016) mengatakan penyebaran pesan menggunakan jejaring sosial merupakan teknik pemasaran yaitu viral marketing.

Viral marketing dapat dilakukan sebagai strategi untuk menerapkan promosi guna menyampaikan informasi dari pemasar pada konsumen. Viral marketing juga merupakan bagian dari WOM (Word of Mouth) karena menggunakan pemasaran dari mulut ke mulut. Perbedaannya terletak pada media yang digunakan dalam menyampaikan informasi. Shukla (2010) mendefinisikan jika penggunaannya secara offline maka itu disebut WOM dan jika penggunaannya secara online maka itulah yang disebut viral marketing atau electronic word of mouth.

Melalui media sosial Instagram, rumah makan Bakso Goreng iONG yang berdiri sejak tahun 2017 dan mampu bertahan di tengah persaingan pasar yang ketat, memiliki jumlah pengikut (followers) pada akun Instagram @baksogorengiong pada Agustus 2019 sebesar 2.958 dan jumlah unggahan (posts) sebanyak 74. Bakso Goreng iONG menjalankan strategi promosi viral marketing video promosi melalui Instagram dengan menggunakan food bloggers.

Menurut Ollie (2012), orang-orang yang menyukai untuk mencoba tempat makan baru dan mengunggah foto-foto makanan tersebut pada blog-nya disebut food bloggers (Viviana dan Candraningrum, 2019). Oleh karena itu, maka terbentuklah sebuah rumusan masalah yaitu adakah pengaruh viral marketing video promosi Instagram terhadap keputusan pembelian konsumen pada produk Bakso Goreng iONG? Tujuan dari dilakukannya penelitian ini adalah untuk mengetahui ada atau tidaknya pengaruh viral marketing video promosi Instagram, terhadap keputusan pembelian konsumen pada produk Bakso Goreng iONG.

Teori yang digunakan dalam penelitian ini adalah media baru, Instagram, electronic word of mouth, viral marketing, dan keputusan pembelian. Menurut Mondry (2008) dalam Perwitasari (2017) new media memiliki fungsi yang privat maupun publik dan media yang menggunakan internet. Salah satu bentuk media baru adalah media sosial. Menurut Scott (2010) media sosial adalah berbagai media yang digunakan oleh manusia, agar dapat saling terhubung dan berkomunikasi satu sama lain dalam dunia maya.

Wifalin (2016) menjelaskan Instagram merupakan aplikasi media sosial (social media) yang berguna bagi para users (pengguna) untuk mengunggah foto, menerapkan filter digital (pemberian efek pada foto), serta membagikannya. Instagram memiliki memiliki fitur yaitu judul, hashtag, lokasi, follow, like, komentar, mentions (tagging) (Atmoko, 2012).

Menurut Henning-Thurau et al. (2004) dalam Wibowo (2015) Electronic Word of Mouth (E-WOM) adalah komunikasi yang positif maupun negatif dan dibuat oleh pelanggan potensial, pelanggan aktual dan mantan pelanggan yang tersedia untuk umum di internet. E-WOM menjadi media komunikasi antara berbagai jenis pelanggan mengenai sebuah produk dari sebuah perusahaan dan dikemukakan untuk umum 
dengan menggunakan internet (online). Menurut Goyette et al dalam Priansa (2017) mengatakan bahwa terdapat dimensi-dimensi yang dapat digunakan untuk mengukur electronic word of mouth, yaitu: (1) Intensity (intensitas); (2) Positive valence (valensi positif); (3) Negative valence (valensi negatif); (4) Content (konten).

Armstrong dan Kotler (2014) mengemukakan bahwa viral marketing merupakan sebuah konsep pemasaran yang menular antara satu pelanggan dengan pelanggan lainnya dengan menyampaikan pesan kepada temannya masing-masing atau versi internet dari penggunaan pemasaran mulut ke mulut yang berhubungan dengan menciptakan e-mail pemasaran. Terdapat komponen dalam berjalannya kegiatan strategi viral marketing. Wahyuni (2016) dalam Varian (2017) membagi komponen viral marketing menjadi tiga bagian, yaitu: konsumen, buzz, kondisi yang mendukung (peer preasure, prestise).

Menurut pendapat Tjiptono (2015), keputusan individu yang secara langsung atau tidak langsung terlibat dalam usaha memperoleh dan menggunakan suatu produk atau jasa yang dibutuhkan disebut keputusan pembelian konsumen. Menurut Kotler dan Keller (2009) tahap-tahap dalam keputusan pembelian yang dilakukan oleh konsumen adalah: (1) Pengenalan masalah; (2) Pencarian informasi; (3) Evaluasi alternatif; (4) Keputusan pembelian; (5) Perilaku pasca pembelian.

\section{Metode Penelitian}

Tipe pendekatan penelitian yang digunakan adalah pendekatan penelitian kuantitatif. Pendekatan penelitian kuantitatif adalah metode-metode yang digunakan untuk menguji teori tertentu dengan menghubungkan antar variabel. Agar data yang terdiri dapat dianalisis, variabel-variabel ini diukur berdasarkan prosedur-prosedur statistik (Creswell, 2012). Metode penelitian deskriptif kuantitatif bertujuan untuk menjelaskan fenomena orang terjadi apa adanya. Menurut Priyono (2016) penelitian deskriptif adalah pemberian gambaran yang lebih rinci terhadap fenomena dan gejala.

Menurut Arikunto dalam Riduwan (2013), populasi merupakan keseluruhan subjek penelitian atau suatu wilayah yang generalisasi, terdiri atas subjek/objek yang mempunyai kuantitas dan karakteristik tertentu yang diterapkan oleh peneliti untuk dipelajari dan kemudian ditarik kesimpulannya. Populasi dalam penelitian ini adalah konsumen Bakso Goreng iONG yang merupakan viewers (penonton) dalam video unggahan akun Instagram @ daddykuliner yang kira-kira berkisaran 1,1 juta penonton.

Keseluruhan objek yang diteliti dan dianggap mewakili seluruh populasi merupakan sampel (Bungin, 2009). Teknik pengambilan sampel yang digunakan adalah nonprobability sampling artinya setiap elemen populasi tidak mempunyai kemungkinan yang sama untuk dijadikan sampel (Darmawan, 2014). Menurut Kusmayadi (2004) dalam Seprina (2014), terdapat 3 jenis cara penarikan sampel dengan teknik non - probability sampling, yaitu accidental sampling, quota sampling, dan purposive sampling. Penelitian ini menggunakan accidental incidental untuk mendapatkan sampel berdasarkan orang-orang yang kebetulan ditemui pada saat melakukan penelitian. Penulis menggunakan rumus Slovin dalam Amirin (2011) dan mendapatkan total sampel sebesar 100 responden.

Kriyantono (2010) mendefinisikan bahwa variabel adalah konsep dalam bentuk konkret atau konsep operasional. Dalam penelitian ini, terdapat variabel bebas dan variabel terikat. Variabel bebas adalah variabel yang diduga sebagai penyebab atau pendahulu dari variabel lainnya, variabel bebas pada penelitian ini adalah viral marketing video promosi melalui Instagram atau dengan kata lain viral marketing (X). 
Variabel terikat adalah variabel yang diduga sebagai akibat atau yang dipengaruhi oleh variable yang mendahuluinya, variabel terikat pada penelitian ini adalah keputusan pembelian konsumen Bakso Goreng iONG atau dengan kata lain keputusan pembelian (Y).

Metode pengumpulan data dalam penelitian ini adalah melalui kuesioner, studi keputsakaan, dan wawancara. Teknik keabsahan data yang digunakan oleh penulis dalam penelitian ini adalah uji validitas, bertujuan untuk mengukur valid atau tidaknya sebuah pernyataan (Nisfiannoor, 2013); uji reliabilitas, menurut Siregar (2013) dilakukan untuk mengetahui hasil yang pasti konsisten, jika adanya pengukuran dua kali atau lebih pada gejala yang sama menggunakan alat pengukur yang sama pula; uji normalitas, bertujuan untuk mengetahui apakah masing-masing variabel berdistribusi normal atau tidak Ghozali (2016); koefisien korelasi (R), merupakan bilangan yang menyatakan bahwa adanya kekuatan hubungan antara dua variabel atau lebih atau juga dapat menentukan arah dari kedua variabel (Siregar, 2013); koefisien determinasi ( $\left.\mathrm{R}^{2}\right)$, untuk mengukur seberapa jauh kemampuan model dalam menerangkan variasi variabel independen Ghozali (2016); analisis regresi sederhana, menurut Kriyanto (2010) bertujuan untuk melakukan prediksi seberapa besar nilai variabel tidak bebas jika nilai variabel bebas diubah; dan uji hipotesis dengan menggunakan uji signifikasi pengaruh parsial (uji T), menguji hipotesis komperatif pada skala interval atau rasio terhadap dua sampel. Uji T digunakan untuk menerangkan seberapa jauh pengaruh satu variabel independen secara individual dalam menjelaskan variasi variabel dependen Ghozali (2016).

\section{Hasil Temuan dan Diskusi}

Penulis menggunakan aplikasi SPSS Statistics 23 dalam pengolahan data. Selama melakukan pengolahan data, penulis mendapatkan beberapa hasil diantaranya adalah sebagai berikut:

- Salah satu komponen dalam berjalannya viral marketing adalah buzz. Dalam indikator content 1 mengenai "tersampaikannya informasi (harga, variasi, rasa) produk makanan Bakso Goreng iONG secara jelas dan menarik pada video promosi Instagram" menunjukkan hasil yaitu sebagian besar responden menjawab sangat setuju bahwa informasi (harga, variasi, rasa) produk makanan Bakso Goreng iONG pada video promosi Instagram tersampaikan dengan jelas dan menarik. Content (konten) adalah kaitan dengan produk dan jasa dari media sosial. Informasi variasi makanan, kualitas, harga, dan sebagainya adalah indikator dari konten.

Informasi produk makanan yang tersampaikan dengan menarik, memperkuat salah satu komponen yang mendukung berjalannya kegiatan strategi viral marketing Wahyuni (2016) dalam Varian (2017) yaitu, buzz, merupakan topik yang hangat, menarik, dan unik. Topik yang hangat, menarik, dan unik mampu membuat orang untuk membicarakan hal tersebut. Berdasarkan hasil wawancara dengan pemilik Bakso Goreng iONG. Dijelaskan bahwa video promosi dibuat dengan memikirkan bagaimana konten yang akan dibuat, agar video yang dihasilkan menarik untuk ditonton.

- Hasil pengolahan data juga menunjukkan bahwa positive valance (pendapat positif) konsumen dalam merekomendasikan kepada teman di kolom komentar, membuat video promosi Instagram dapat tersebar dengan luas dan cepat, dikarenakan adanya rekomendasi yang diberikan kepada 
kawan/keluarga. Dalam indikator positive valance 2 mengenai "merekomendasikan kepada teman mengenai produk makanan Bakso Goreng iONG pada kolom komentar video promosi Instagram Bakso Goreng iONG", menunjukkan hasil yaitu sebagian besar responden setuju dengan pernyataan konsumen merekomendasikan kepada teman mengenai produk makanan Bakso Goreng iONG pada kolom komentar video promosi Instagram Bakso Goreng iONG.

Artinya, konsumen memberikan rekomendasi kepada pengguna situs media sosial lainnya. Dengan adanya komentar rekomendasi kepada pengguna situs media sosial, membuat video semakin luas tersebar. Berdasarkan hasil wawancara penulis dengan pemilik Bakso Goreng iONG, dikatakan bahwa komentar yang masuk pada kolom komentar juga merupakan komentar yang isinya mengenai ajakan kepada teman/keluarga.

- Konsumen Bakso Goreng iONG terbukti memutuskan untuk membeli produk, dengan adanya hasil pernyataan bahwa setelah melihat video promosi Instagram. Pada indikator keputusan pembelian 1 mengenai "memutuskan untuk membeli produk makanan Bakso Goreng iONG setelah melihat video promosi Instagram", menunjukkan bahwa responden sangat setuju dengan pernyataan bahwa konsumen memutuskan untuk membeli produk makanan Bakso Goreng iONG setelah melihat video promosi Instagram. Konsumen memutuskan untuk membeli produk Bakso Goreng iONG. Pernyataan ini juga didukung dengan hasil wawancara penulis dengan pemilik Bakso Goreng iONG, bahwa omset penjualan mengalami peningkatan dengan adanya video promosi Instagram tersebut. Oleh karena itu, dapat disimpulkan bahwa ada pengaruh viral marketing video promosi Instagram terhadap keputusan pembelian konsumen Bakso Goreng iONG.

- Berikut hipotesis dari penelitian ini:

- Hipotesis Nol (Ho): tidak ada pengaruh viral marketing video promosi Instagram terhadap keputusan pembelian konsumen Bakso Goreng iONG.

- Hipotesis Alternatif (Ha): terdapat pengaruh viral marketing video promosi Instagram terhadap keputusan pembelian konsumen Bakso Goreng iONG.

Berdasarkan hasil uji T menunjukkan bahwa hasil uji T dengan (sig.) sebesar 0.000 yang artinya Ha diterima. Dengan Ha diterima, memiliki arti bahwa viral marketing video promosi Instagram memiliki pengaruh yang positif terhadap keputusan pembelian konsumen Bakso Goreng iONG. Dengan adanya strategi pemasaran viral marketing yang baik, dapat mendorong seseorang untuk membeli produk dari Bakso Goreng iONG. Dalam penelitian ini, terdapat beberapa komponen yang mendukung berjalannya strategi pemasaran viral marketing.

- Uji koefisien korelasi bertujuan untuk menyatakan bahwa adanya kekuatan hubungan antara dua variabel atau lebih (Siregar, 2013). Hasil menunjukkan, koefisien korelasi $(\mathrm{R})$ untuk variabel viral marketing $(\mathrm{X})$ adalah sebesar 0.331. Oleh karena itu, hubungan antara $\mathrm{X}$ dan $\mathrm{Y}$ dikatakan cukup karena berada dalam interval $0,25<\mathrm{R} \leq 0,5$. Terdapat kekuatan yang bernilai cukup hubungan antara variabel viral marketing (X) dan variabel keputusan pembelian (Y). Jika koefisien korelasi bernilai positif, maka kedua variabel mempunyai hubungan searah, jadi jika nilai variabel $\mathrm{X}$ tinggi, maka nilai 
variabel Y juga tinggi (Sarwono, 2009). Maka dapat disimpulkan bahwa kedua variabel mempunyai hubungan searah. Dengan nilai 0.331 memiliki positif, jika variabel viral marketing (X) bernilai besar, maka variabel keputusan pembelian (Y) juga bernilai besar.

\section{Simpulan}

Penggunaan viral marketing melalui video promosi Instagram memiliki pengaruh yang positif terhadap keputusan pembelian konsumen Bakso Goreng iONG. Dengan adanya strategi pemasaran viral marketing yang baik, dapat mendorong seseorang untuk membeli produk dari Bakso Goreng iONG. Salah satu komponen dalam mendukung berjalannya viral marketing adalah $b u z z$, yang merupakan isi, ide dan topik dari video promosi yang disampaikan. Dengan topik yang menarik dan jelas mengenai informasi dari produk yang dipasarkan oleh Bakso Goreng iONG, membuat konsumen Bakso Goreng iONG tertarik untuk membeli produk Bakso Goreng iONG. Positive valance (pendapat positif) juga mendukung berjalannya viral marketing, konsumen merekomendasikan kepada teman dalam kolom komentar. Dengan penyebaran ini, membuat video promosi Instagram dapat tersebar dengan luas dan cepat, dikarenakan adanya rekomendasi yang diberikan kepada kawan/keluarga.

Konsumen Bakso Goreng iONG terbukti memutuskan untuk membeli produk, dengan adanya hasil pernyataan bahwa setelah melihat video promosi Instagram, konsumen memutuskan untuk membeli produk Bakso Goreng iONG. Pernyataan ini juga didukung dengan hasil wawancara penulis dengan pemilik Bakso Goreng iONG, bahwa omset penjualan mengalami peningkatan dengan adanya video promosi Instagram tersebut. Oleh karena itu, dapat disimpulkan bahwa ada pengaruh viral marketing video promosi Instagram terhadap keputusan pembelian konsumen Bakso Goreng iONG.

\section{Ucapan Terima Kasih}

Penulis ingin mengucapkan terima kasih kepada para narasumber yang telah mengisi kuesioner mengenai video promosi Instagram Bakso Goreng iONG dan juga pemilik Bakso Goreng iONG yang telah diwawancarai. Serta para dosen Fakultas Ilmu Komunikasi Universitas Tarumanagara yang telah memberikan ilmu kepada penulis.

\section{Daftar Pustaka}

Amirin, Tatang Manguni. (2011). Populasi dan sampel penelitian 4: Ukuran sampel rumus Slovin. Jakarta: Erlangga.

Bungin, Burhan. (2009). Analisis Penelitian Data Kualitatif. Jakarta: Raja Grafindo.

Creeber, Glen, \& Martin, Royston. (2009). Digital Cultures: Understanding New Media. Berkshire-England.

Creswell, John, W. (2012). Research design pendekatan kualitatif, kuantitatif, dan mixed, Pustaka Pelajar.

Darmawan, Deni. (2014). Metode Penelitian Kuantitatif. Bandung: PT. Ramaja Posdakarya.

Ghozali, Imam. (2016). Aplikasi Analisis Multivariete dengan Program IBM SPSS 23, Edisi Delapan. Semarang: Badan Penerbit Universitas Diponegoro. 
Velia, Diah Ayu Candraningrum: Pengaruh Viral Marketing Video Promosi Instagram Terhadap Keputusan Pembelian Konsumen Bakso Goreng iONG

Kaloka, A. S. K. (2016). November 11, 2019. Pengaruh Viral Marketing Terhadap Minat Beli Konsumen Melalui Kepercayaan Konsumen Pada Instagram @MAKANANJEMBER. Terarsip http://repository.unej.ac.id/handle/123456789/79352

Kotler, Philip, \& Armstrong, Gary. (2014). Principles of Marketing fifteenth. England: Pearson Education Limited.

Kriyantono, Rachmat. (2010). Teknik Praktis Riset Komunikasi. Jakarta: kencana.

Mulyana, Deddy. (2013). Komunikasi efektif "Suatu Pendekatan Lintas Budaya". Bandung: PT. Remaja Rosdakarya.

Nisfiannoor, Muhammad. (2013). Pendekatan Statistika Modern Aplikasi dengan Software SPSS dan E-Views. Jakarta: Penerbit Universitas Trisakti.

Perwitasari, Dian. (2017). Desember 6, 2019. Tema Konflik Pacaran di Media Sosial Instagram (Analisis Isi Video Pada Akun@ alfysaga Periode 01 November 2016-31 Januari 2017) (Doctoral dissertation, University of Muhammadiyah Malang). Terarsip di http://eprints.umm.ac.id/35409/

Priyono, M. (2016). Metode penelitian kuantitatif. Sidoarjo: Zifatma Publishing.

Riduwan. (2013). Skala Pengukuran variabel-variabel Penelitian. Bandung: Alfabeta

Sarwono, Jonathan. (2009). Statistik itu Mudah: Panduan Lengkap untuk Belajar Komputerisasi Statistik Menggunakan SPSS. Yogyakarta: Andi.

Scott, David Meerman. (2010). The New Rules of Marketing and PR: How to use News Releases, Blogs, Blogs, Podcasting, Viral Marketing and Online Media to Reach Buyers Directly. Hoboken, New Jersey.

Seprina, Heni. (2014). Oktober 9, 2019. Persepsi Wisatawan Terhadap Obyek Wisata Air Terjun Way Lalaan di Pekon Kampung Baru Kecamatan Kota Agung Timur Kabupaten Tanggamus Tahun 2013. Terarsip di http://digilib.unila.ac.id/4512/

Shukla, T. (2010). September 3, 2019. Factors affecting'Internet marketing'campaigns with reference to viral and permission marketing. The IUP Journal of Management Research, 9(1), 26-37. Terarsip di https://www.researchgate.net/profile/Timira_Shukla/publication/228321574

Siregar, Syofian. (2013). Metode penelitian kuantitatif. Jakarta: kencana.

Tjiptono, Fandy. (2015). Strategi Pemasaran Edisi 4. Yogyakarta: Andi.

Viviana, C., \& Candraningrum, D. A. (2019). September 3, 2019. E-Wom Oleh Kalangan Milenial Terhadap Akun@ makansampaikenyang Sebagai Pemberi Rekomendasi Kuliner. Prologia, 2(2), 270-277. Terarsip di https://journal.untar.ac.id/index.php/prologia/article/view/3587

Wifalin, Michelle. (2016). September 10, 2019. Efektivitas Instagram Common Grounds. Jurnal E-Komunikasi, 4(2). Terarsip di http://publication.petra.ac.id/index.php/ilmu-komunikasi/article/view/4853

Wibowo, Arif. (2015). September 10, 2019. Pengaruh Elektronik Word Of Mouth dan Brand Image Terhadap Purchase Intention Pada Konsumen Smartphone Samsung Yang Berbasis Android. Jurnal Ilmu Manajemen, 12(1), 71-88. Terarsip di https://media.neliti.com/media/publications/101266-ID-pengaruhelektronik-word-of-mouth-dan-br.pdf

Varian, Christopher. (2017). September 3, 2019. strategi viral marketing produk chitato indomie di instagram dalam membangun brand awareness (Doctoral dissertation, Universitas Multimedia Nusantara). Terarsip di http://kc.umn.ac.id/2699/ 